Article

\title{
What Affects Chinese Households' Behavior in Sorting Solid Waste? A Case Study from Shanghai, Shenyang, and Chengdu
}

\author{
Yanmin $\mathrm{He}^{1, *}$, Hideki Kitagawa ${ }^{2}$, YeeKeong Choy ${ }^{3}$, Xin Kou ${ }^{4}$ and Peii Tsai ${ }^{5}$ \\ 1 Faculty of Economics, Otemon Gakuin University, Osaka 567-8502, Japan \\ 2 Faculty of Policy Science, Ryukoku University, Kyoto 612-8577, Japan; kitagawa@policy.ryukoku.ac.jp \\ 3 Faculty of Economics, Keio University, Tokyo 108-8345, Japan; choy3293@gmail.com \\ 4 School of Management, Shenyang Jianzhu University, Shenyang 110015, China; cat.1639@hotmail.com \\ 5 GCI, Yokohama City University, Yokohama 236-0027, Japan; peii.tsai555@gmail.com \\ * Correspondence: kaenmin@hotmail.com; Tel.: +81-72-665-5371
}

Received: 22 September 2020; Accepted: 22 October 2020; Published: 23 October 2020

\begin{abstract}
The main aim of this study was to examine residents' environmental behavior in sorting solid household waste, and to identify the integrative factors that contribute to their waste-separation cooperation and other related pro-environmental behaviors. This was achieved based on a questionnaire survey in Shenyang, Chengdu, and Shanghai. Methodologically, we applied a discrete choice model to examine whether individuals' garbage sorting behaviors differ based on their characteristics, social attributes, residential circumstances, and environmental awareness, and whether these factors are correlated with individuals' receptiveness to a refuse charge system, or to policies requiring garbage sorting. We further examined whether individuals' garbage sorting behavior, their receptiveness to fee-based waste collection, and their receptiveness to policies requiring garbage sorting differ across areas. In this particular survey, we introduced a 16 item scale of pro-environmental behavior and a nine item scale of altruism to ascertain the ways in which internal motivational factors affect people's environmentally conscious voluntary behavior. Overall, the present work is expected to contribute to an important understanding of the motivational forces and incentives behind human pro-environmental behavior and action. It also brings relevance to the analysis of moral solidarity in relation to the household waste disposal problems currently confronting us today.
\end{abstract}

Keywords: municipal solid waste; garbage sorting behavior; environmental awareness; pro-environmental behavior; altruism

\section{Introduction}

Rapid economic growth, urbanization, and the steep growth in the global population and consumption rate have resulted in increased waste production at an unprecedented rate. In 2016, the worlds' cities generated 2.01 billion tonnes of municipal solid waste (MSW). East Asia and Pacific regions currently generate most of the world's waste, at 23\% (468 million tonnes). However, the fastest growing regions in waste generation are Sub-Saharan Africa and South Asia, where the total waste generation is expected to more than double by 2050 , making up 35\% of the world's waste. The Middle East and North Africa regions are also expected to double their waste generation by 2050. It is also noteworthy that at least 33\% of the global MSW is not managed in an environmentally safe manner. Ineffective waste management will cause serious air, soil, and groundwater pollution. This will not only hamper sustainable urban environment but will also threaten the health of residents [1]. Chen et al. shows that, without stringent policy directives, due to both the strong continued growth of the total waste generation and the slow increase of sustainable treatment shares, there is no absolute decoupling 
effect for the waste observed as countries become richer (with the exception of Japan, where other institutional and cultural factors may play a role), and there is thus little evidence for a waste-related environmental Kuznets curve [2]. It thus follows that sustainable waste management will be a major challenge for many countries, especially developing countries, in the coming decade.

However, effective waste management is costly, often taking up $20 \%$ to $50 \%$ of municipal budgets [3]. With limited funding, citizen engagement involving behavioral change and public participation has become one of the most cost-effective means in promoting sustainable waste management [4]. Many countries-such as Korea, the Philippines, and Thailand-use behavior-changing variable fees to motivate waste reduction, source-separation, and reuse. In Nepal, the government uses results-based financing to create a sustainable behavioral change in waste disposal, while in Jamaica, the government employs various educational strategies to induce behavioral change in safe and environmentally-friendly waste disposal practices [1].

In view of the far-reaching environmental and health repercussions arising from continued and increased waste production, sustainable solid waste management is every country's business. This is particularly true for China, which has the largest population in the world. Demonstrably, China generates large volumes of MSW annually due to its huge population and high consumption rates. In 2016, about 47 percent (220 million tonnes) of waste in the East Asia and Pacific regions was generated by China, although its daily per capita waste generation rate of $0.43 \mathrm{~kg}$ is below the regional average of $0.56 \mathrm{~kg}$ [1]. In addressing its increased waste production problems, China has also adopted various environmental behavioral control strategies to induce sustainable household waste generation, separation, and disposal practices. The present article aims to examine the empirical evidence of the determinants of household environmental behavior in MSW management in China.

To begin with, the impressive economic growth in China for the past few decades has accompanied rapid and massive urbanization across the country. Inevitably, this has given rise to one of the most formidable challenges facing the country today: the MSW problem. Viewed from China's perspective, MSW includes solid wastes defined under national laws and administrative regulations, as well as solid wastes discharged from residents' daily activities or from the necessary services provided for such activities. In general, MSW is categorized into household solid waste, commercial solid waste, market solid waste, solid waste from street cleaning, solid waste from public facilities, and business-related solid waste. In this paper, we focus our research on the city's daily household solid waste (HSW).

In 2017, the amount of HSW collected and transported to HSW disposal sites and final disposal facilities located nationwide reached approximately 200 million metric tonnes [5]. The massive amount of HSW has intuitively given rise to an urgent need for the government to establish a proper solid waste management system in order to contain its environmentally destructive effects. It may well be that the improper handling of HSW can cause soil contamination, foul odors, water pollution, and other environmental problems, which impair human health and hamper urban sustainable development.

In light of the above, it may be remarked that rapid urbanization and the improvement of people's living standards have significantly raised human environmental awareness and interest in environmental issues, especially in relation to HSW disposal. However, the local communities where 'Not In My Back Yard' (NIMBY) facilities are located, especially in developing countries with high population densities, have quite strongly opposed land acquisitions for the development of solid waste disposal sites. In China, annually, and with more than five anti-incinerator demonstrations, local residents have claimed the relocation of municipal solid waste incineration facilities from 2007 to 2016, and the facility that would benefit the public the most was aborted. This caused a drastic lack of disposal sites or land resources for the safe disposal of HSW [6,7].

In order to address the above issues, the Chinese government launched its HSW sorting policy within eight cities in the early 2000s as a sustainable waste management pilot project under the auspices of the Ministry of Construction, in order to encourage waste minimization in all of the sectors of the community. Nonetheless, the project was poorly implemented, and failed to achieve its aim as expected. 
Indisputably, if the HSW problem is left unmitigated, it would exert great impacts in upsetting the government's vision of an 'Ecological Civilization' (EC).

The EC is a political vision introduced in 2007 by the former president, Hu Jintao. It aims to uphold harmony between humanity and nature as one of the basic strategies to promote sustainable development, especially in relation to pollution reduction, a circular economy, a low-carbon economy, and green development. As regards MSW, the green concept of ecological civilization was formally endorsed under China's Circular Economy Promotion Law in 2009, as discussed below. The EC concept was progressively elevated to the rank of a paramount objective of the Chinese Communist Party (CCP) during the 18th National People's Congress of the Communist Party of China, held in 2012. It was further enshrined as a constitutional principle in the Constitution of the People's Republic of China (PRC) in 2018 [8].

It is worth reiterating, in light of the foregoing, that the EC vision is distinctly concerned with the orientation of a low-carbon, eco-friendly, and resource-efficient society that underpins the promotion of a green economy. Here, it may be remarked that proper waste disposal is related to not only the reuse/recycling of resources, but also to the creation of a sustainable society through the optimal utilization of waste as an urban energy source. A case in point is the transformation of household kitchen garbage into biogas. Increasingly, efforts to promote the separate collection of HSW based on the guiding principles of garbage reduction, recycling, and detoxification have attracted the attention of many individuals in various parts of China in recent years [9].

Generally speaking, solid waste management comprises two methods of waste collection, namely, a fixed-price system and a quantity-based pricing system. A municipality with a fixed-price system charges a fixed fee per household or household member for waste disposal, regardless of the amount of garbage originating from the household. The fee is not linked to the amount of garbage discarded, so the system is not very effective in reducing the amount of garbage disposed. In contrast, for the quantity-based pricing system, the fee levied for waste disposal changes in accordance with the amount of garbage discarded. One prominent example is the paid garbage bag system, which requires residents to use garbage bags that meet certain standards (designated bags).

Manifestly, there have been various legislations put in place to promote sustainable HSW management in China. One of the most prominent legal instruments is China's Circular Economy Promotion Law, which was implemented in 2009, as briefly noted above. It legislates the principles of waste reduction, reuse, and recycling. Moreover, the government controlling bodies-such as the Ministry of Environmental Protection (MEP), the Ministry of Housing and Urban-Rural Development (MOHURD), and the National Development and Reform Commission (NDRC)—also play an important role to ensure effective law enforcement and observation. The local People's Governments also enact various regulations and measures to strengthen the sustainable disposal and recycling of HSW practices. For example, in 2011, the State Council issued a Notice on the Opinions on Further Strengthening the Work of Municipal Solid Waste Disposal (State Council, 2011, document No. 9) to reinforce sustainable HSW practices [10]. It further introduced new HSW disposal fees based on a 'discarder pays principle', which is similar to the 'polluter pays principle' (those, irrespective of being consumers or producers, who generate it are the ones who pay). Subsequently, efforts to promote waste sorting and waste reduction via the implementation of the fee-based waste disposal principle have become active at the local government level.

Despite these novel efforts, casual observation on the ground seems to indicate that they have not been able to contribute effectively to foster proper waste-sorting habit-formation among the residents. Furthermore, the separation of HSW was also not properly maintained after collection in conformity with the stipulated waste segregation guidelines. Experience shows that waste still remains practically unsorted. Worse yet, the residents were indifferent to the adoption of the green principles of waste sorting and separation in line with the EC concept. In order to resolve these problems, the State Council issued the Proposed Method of Implementing the Sorting System for Municipal Solid Waste [11] in 
March 2017, with the aim to mandate the separate collection of HSW in 46 designated cities by the end of 2020 .

Against this backdrop, the present study aims to assess the effects of the new mandate on the behavioral change of waste sorting and separation in three selected regions out of the 46 designated pilot cities, namely, Shanghai, Shenyang (Liaoning Province), and Chengdu (Sichuan Province). This is achieved based on questionnaire surveys. In particular, the questionnaire research aims to examine residents' behavior in sorting HSW. This covers the assessment of the factors that contribute to residents' receptiveness of waste separation policies, as well as other variables in relation to sustainable HSW management. The latter include personal demographics, personal attitudes, external moderators such as circumstances and economic incentives, and internal moderators such as environmental concerns and human altruism.

\section{Literature Review}

The separate collection of HSW makes it possible to sustainably curb the amount of garbage generated at its sources and mitigate its adverse environmental impacts at the final disposal sites. Requiring households to sort garbage, however, burdens the government with an enormous cost of monitoring compliance. Therefore, the effectiveness of waste management requirements strongly depends on whether the household residents comply with them without being monitored or coerced. However, the reality is that the waste sorting programs, as implemented by the government, often fail to persuasively induce residents to comply with the guidelines as stipulated [12].

That said, to enhance the effectiveness of garbage sorting compliance, it is necessary to influence household residents' waste disposal behavior. Linde' $\mathrm{N}$ and Carlsson-Kanyama [13] and Antonides and van Raaij [14] divide the factors that affect residents' waste disposal behavior into external motivational factors and internal motivational factors. External motivational factors include administrative measures, such as laws and regulations, economic measures, information measures, and physical measures. The authors concerned posit that a policy package that combines an assortment of these four measures can affect residents' garbage sorting behavior. Insofar as the internal motivational factors are concerned, environmental knowledge, environmental concern, environmental values and attitudes, behavioral preferences, lifestyle preferences, and social influence are often considered to be some of the important motivating means of behavioral change [8].

On the other hand, Lindhqvist unveiled three factors that promote the separate collection of household garbage, namely, economic incentives, the level of convenience associated with discarding garbage, and information [15]. However, Dahlén and Lagerkvist argue that access to opportunities and places for separate disposal is an important factor affecting the rate of separate collection [16]. In addition, Chappells et al. assert that the introduction of a system that monitors the separate disposal of garbage encourages proper garbage sorting behavior [17]. Others, such as Judge and Becker [18], Linde' $\mathrm{N}$ and Carlsson-Kanyama [13], and Ando and Gosselin [19] emphasize the effects of the placement of bins, the ease of sorting garbage, and increased convenience in terms of the timing of garbage collection. Houtven and Morris, however, argue that residential ownership has a noticeable effect on the household's waste generation and disposal behavior [20].

From China's perspective, Ghorbani et al. argue that members of the Communist Party of China (CPC) and the All-China Federation of Trade Unions not only have a stronger environmental awareness, but also a greater willingness to pay for environmental protection activities than the general public [21]. Similarly, Clark et al. claim that being altruistic and having environmentally friendly attitudes affects people's environmentally-conscious voluntary behavior, and that altruistically inclined individuals are more likely to participate in a green electricity program [22]. People with a strong sense of place or belonging to their city or community tend to actively participate in the city's government activities. A sense of place may be defined as the meaning ascribed, and the attachment formed, to a place by an individual or communities. This sense of place may be grounded on the emotional values that individuals ascribe to the surrounding environment [23-25]. Another factor that strongly influences 
an individual's sense of belonging to their city or community is the sense of one's own status. Here, it is appropriate to remark that, in China, people's household registration cannot be freely changed. Thus, even within a city, there is a stark difference between those who have an urban household registration and those who have a rural household registration. In view of this, an individual's sense of their own status may impact considerably on their degree of their sense of belonging to their city or community. For this reason, this study takes into account the survey respondents' household registration status, with a view to ascertain the relationship between a sense of place, a sense of belonging, and environmental behavior in relation to HSW disposal.

The above studies provide sufficient indication that there are many factors that influence one's environmental behavior and action. However, as regards China, it is unclear as to what categories of factors or behavioral determinants contribute to drive an individual's environmental behavioral change. Against this premise, what follows is an attempt to examine the motivational forces and other integrative factors that underpin household residents' garbage sorting habits.

\section{Materials and Methods}

\subsection{Research Hypotheses and Model}

Environmental behavior is not only related to social and economic factors. We must never lose sight of the fact that it is also unalterably affected by the levels of environmental knowledge, environmental awareness, and environmental concern. Following logically from this line of thought, and inspired by the work of Rylander and Allen, we introduce an internal variable of altruistic attitudes into an integrative environmental behavioral framework in order to assess the motivational forces that influence an individual's pro-environmental behavior (Figure 1) [26]. The framework considers demographic variables and knowledge to be the integrative factors that shape individual attitudes towards environmentally friendly behavior. Here, it must be admitted that attitudes do not necessarily influence receptiveness directly, as their effect is moderated by multifaceted internal and external variables, such as environmental concern, altruism, information, and economic incentives. The close link between attitudes and receptiveness may be the most tenuous aspect of the model. This study attempts to examine whether individuals' garbage sorting behavior is contingent on their characteristics, social attributes, residential circumstances, or environmental awareness. We also consider whether these factors are correlated with individuals' receptiveness to garbage sorting behavior, to fee-based waste collection, or to policies requiring garbage sorting. Here, it may be noted that our research is premised on self-reported receptiveness, which may be over-stated by the respondents concerned.

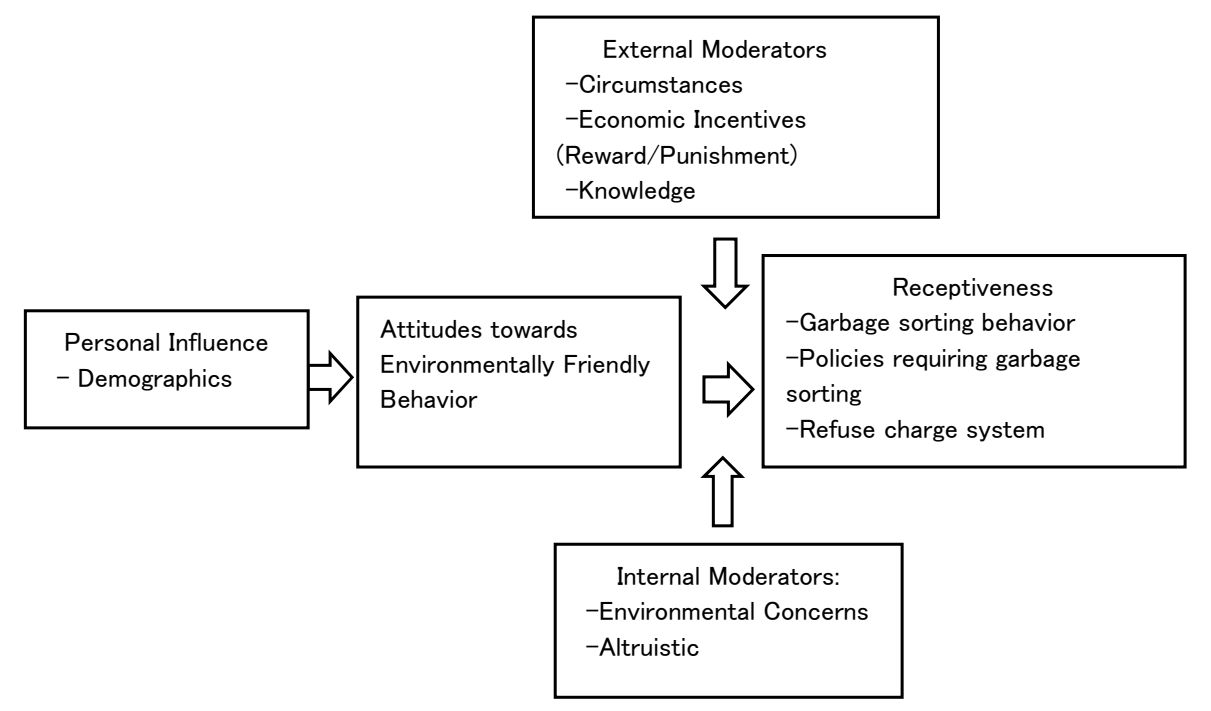

Figure 1. The research framework. 


\subsection{Survey Area}

The survey was conducted in Shanghai, Shenyang, and Chengdu, which are representative cities of the eastern region, northern region, and western region of China, respectively (Figure 2). In 2017, the permanent registered population was 14.55 million in Shanghai, 7.4 million in Shenyang, and 14.35 million in Chengdu. The annual GDP was 3063.3 billion yuan in Shanghai, 586.5 billion yuan in Shenyang, and 1388.9 billion yuan in Chengdu in 2017 [27].

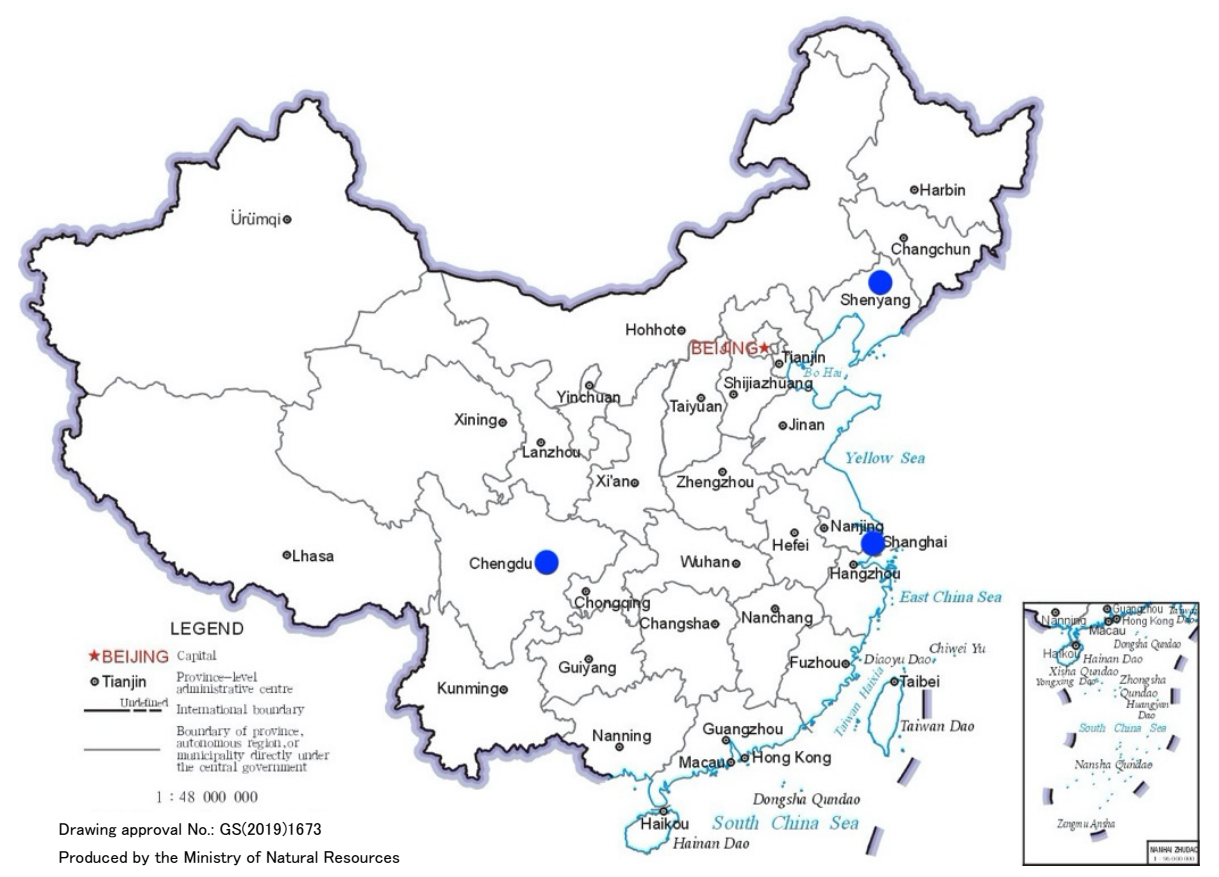

Figure 2. Location map of Shanghai, Shenyang, and Chengdu. Source: Ministry of Natural Resources of the People's Republic of China (PRC).

Generally, these three cities categorize household garbage into four types: recyclable, hazardous, biodegradable (specifically known as 'wet waste' in Shanghai), and other waste (categorically called 'dry waste' in Shanghai). Both Shanghai and Chengdu stipulate local rewards for residents' sorting behaviors. Shanghai was selected in June 2000 for the implementation of China's first nationwide pilot program for garbage separation and collection, along with Beijing, Nanjing, Hangzhou, Guilin, Guangzhou, Shenzhen, and Xiamen. As past experience reveals, a high monitoring cost makes it hard for the government to constantly detect the separation of solid waste from each household. It is therefore necessary to introduce some kind of incentive to induce social conscience for sustainable waste disposal behavior and practices.

In 2014, the Shanghai Huizhong Green Corporate Social Responsibility was established, with the aim to encourage citizens to sort kitchen garbage and other waste based on an economic incentive system, called the Green Account program. Under this system, one Green Account card is issued to one household upon request. If the household discards sorted kitchen garbage during the designated hours (7:00 to 9:00 in the morning, and 17:00 to 19:00 in the evening), it receives ten points each time (up to a maximum of 20 points per day). The points received are valid for two years, and can be exchanged for everyday items, movie tickets, or park tickets, among other things [28,29].

In Chengdu, Sichuan Province, the Chengdu Green Earth Environment Technology Co., a pioneer in the waste classification field in China, introduced the Green Earth program in 2008, with the aim to encourage residents to sort recyclable waste. Green Earth provides each family with a unique barcode sticker that can be put on the trash bag for identification. Households can receive reward points based on the weight of the trash bags placed in the designated recycling bins. For example, every $100 \mathrm{~g}$ of normal recyclable garbage (paper, plastic, and metal), every $200 \mathrm{~g}$ of glass, or every $500 \mathrm{~g}$ of clothes 
will receive one green point. The points received are valid for two years, and can be exchanged for detergents, toothpastes, and other everyday items [30].

\subsection{Questionnaire}

The questionnaire comprised eight sections: social demographic information, circumstances, behavior, knowledge, receptiveness, a pro-environmental behavior scale, and an altruism scale. Table 1 shows the question items for all of the respondents.

Table 1. Question items.

\begin{tabular}{|c|c|}
\hline Demographic Information & $\begin{array}{c}\text { Gender, age, occupation, education level, marital status, residence type and } \\
\text { ownership, income, household registration status, years residing, } \\
\text { political affiliation }\end{array}$ \\
\hline $\begin{array}{l}\text { Circumstances of discarding } \\
\text { sorted household garbage }\end{array}$ & $\begin{array}{l}\text { Rules on garbage sorting, equipment at garbage collection spot, time to } \\
\text { collection spot, elevator exists or not, frequency of garbage disposal }\end{array}$ \\
\hline $\begin{array}{l}\text { Knowledge on sorting } \\
\text { household garbage }\end{array}$ & $\begin{array}{c}\text { Knowledgeable or not knowledgeable about garbage sorting, have or do not } \\
\text { have the correct knowledge on garbage sorting }\end{array}$ \\
\hline $\begin{array}{l}\text { Behavior related to sorting } \\
\text { household garbage }\end{array}$ & Pre-disposal sorting at home or not, end-point sorting at collection spot or not \\
\hline Economic incentives & $\begin{array}{l}\text { On the Green Account program in Shanghai: } \\
\text { - Knowledgeable or not knowledgeable about the Green Account } \\
\text { - Knowledgeable or not knowledgeable about the purpose of the } \\
\text { Green Account } \\
\text { - Knowledgeable or not knowledgeable about the use of the Green Account } \\
\text { On the Green Earth program in Chengdu: } \\
\text { - Knowledgeable or not knowledgeable about the Green Earth program } \\
\text { - Knowledgeable or not knowledgeable about the purpose of the Green } \\
\text { Earth program } \\
\text { - Knowledgeable or not knowledgeable about the use of the Green } \\
\text { Earth program } \\
\text { In Shenyang, we used the following hypothetical question, because there is no } \\
\text { economic incentive yet: } \\
\text { - Do you agree or not agree with the “Pay-As-You-Throw" program? }\end{array}$ \\
\hline $\begin{array}{l}\text { Receptiveness to policies } \\
\text { requiring garbage sorting }\end{array}$ & Support or oppose garbage sorting \\
\hline $\begin{array}{l}\text { Receptiveness to a refuse } \\
\text { charge system }\end{array}$ & $\begin{array}{c}\text { Support or oppose quantity-based charging for garbage collection, amount } \\
\text { willing to pay for a refuse charge system, charging method (charging } \\
\text { according to water use fee, charging designated bags, charging according to } \\
\text { the number of household members, or charging according to } \\
\text { household income) }\end{array}$ \\
\hline Other scales & $\begin{array}{l}\text { Pro-environmental behavior scale } \\
\text { Altruism scale }\end{array}$ \\
\hline
\end{tabular}

\subsection{Sample Characteristics}

The empirical research was conducted in two stages. Firstly, data were collected by a preliminary survey (300 people) in September 2017 as a pretest; secondly, a main survey (2100 people) was conducted through an online platform (Wen Juan Xing). The present research was analyzed based on the data accumulated from the main survey. The main survey, which involved various groups of adults aged between 18 and 70 years, was conducted between December 2017 and the end of January 2018. A sample of 2100 adults between 18 and 69 years old was randomly selected from the local population. After the elimination of responses with outliers and missing values, the number of valid responses was 612 for Shanghai, 484 for Shenyang, and 525 for Chengdu (1621 in total).

The demographic composition of the sample is shown in Table 2. In terms of the respondents' gender, the sample contains slightly more females than males ( 819 women vs. 802 men). As for the 
age category, the number of respondents in their 40s is the largest, and the number of respondents in their 60s is significantly smaller (505 respondents aged 18 to 29 years, 439 respondents in their 30s, 535 respondents in their 40s, 126 respondents in their 50s, and 16 respondents aged 60 years and over). The smaller number could be attributed to the low rate of internet use among seniors. The sample consists of 124 respondents who have achieved a middle school diploma or obtained a lower educational achievement, 456 respondents with a high school or specialized school diploma, 944 respondents with a university or advanced specialized school diploma, and 97 respondents with a graduate school diploma. It is thus clear that $54 \%$ of the respondents have completed at least a university-level education. The sample is more or less evenly split between those who have political affiliation and vice versa: 308 Communist Party of China members, 348 Communist Youth League members, 21 members of other non-communist or minor parties, 879 respondents with no political affiliation, and 65 respondents identified as 'other.' The number of respondents who had a household registration for their area of residence (referred to as 'natives') is 916 , which is higher than the number of respondents who did not have a household registration for their area of residence (referred to as 'outsiders'), which is 705. The gender ratio, education, and income level are all consistent with the Statistical Yearbook. Hence, the survey reflects the real situation in the three cities under consideration.

Table 2. The profile of subjects $(\mathrm{N}=1621)$.

\begin{tabular}{|c|c|c|}
\hline & N (number) & Percentage $(\%)$ \\
\hline \multicolumn{3}{|l|}{ Gender } \\
\hline Male & 802 & 49.5 \\
\hline Female & 819 & 50.5 \\
\hline \multicolumn{3}{|l|}{ Age } \\
\hline $18-29$ & 505 & 31.2 \\
\hline $30-39$ & 439 & 27 \\
\hline $40-49$ & 535 & 33 \\
\hline 50-59 & 126 & 7.8 \\
\hline 60 or above & 16 & 1 \\
\hline \multicolumn{3}{|l|}{ Education level } \\
\hline Junior high and below & 124 & 7.7 \\
\hline Senior high or senior secondary & 456 & 28.1 \\
\hline Undergraduate or junior college & 944 & 58.2 \\
\hline Postgraduate or above & 97 & 6 \\
\hline \multicolumn{3}{|l|}{ Occupation } \\
\hline Administrative & 33 & 2 \\
\hline Public-sector organizations & 162 & 10 \\
\hline State-owned enterprise & 265 & 16.3 \\
\hline Private enterprise & 411 & 25.4 \\
\hline Social organization & 17 & 1.1 \\
\hline Self-employed/liberal profession & 176 & 10.9 \\
\hline Foreign capital enterprise & 133 & 8.2 \\
\hline Farming, forestry, fishery workers, or others & 123 & 7.6 \\
\hline Housewife & 66 & 4.1 \\
\hline Retired & 36 & 2.2 \\
\hline Student & 88 & 5.4 \\
\hline Unemployed & 21 & 1.3 \\
\hline Others & 90 & 5.6 \\
\hline \multicolumn{3}{|l|}{ Income (RMB, thousand yuan) } \\
\hline $1-3$ & 184 & 11.2 \\
\hline $3.001-6$ & 435 & 26.5 \\
\hline $6.001-9$ & 335 & 20.7 \\
\hline $9.001-12$ & 215 & 13.3 \\
\hline $12.001-15$ & 167 & 13.3 \\
\hline $15.001-20$ & 125 & 7.71 \\
\hline 20.001-30 & 81 & 5 \\
\hline 30.001 or above & 79 & 4.9 \\
\hline
\end{tabular}


Table 2. Cont.

\begin{tabular}{ccc}
\hline & N (number) & Percentage (\%) \\
\hline Political affiliation & & \\
Member of the Communist Party of China (CPC) & 308 & 19 \\
Member of the Communist Youth League of China & 348 & 21.5 \\
Member of other non-communist or minor parties & 21 & 1.3 \\
Commoner & 879 & 54.2 \\
Other & 65 & 4 \\
Marital status & & \\
Single & 396 & 24.4 \\
Married & 1184 & 73 \\
Other & 41 & 2.5 \\
Nousehold registration status & & \\
Native & 916 & 56.5 \\
Outsiders & 705 & 43.5 \\
\hline
\end{tabular}

Source: authors' own calculations, 2020.

\section{Data Analysis and Results}

\subsection{Descriptive Statistics}

It was uncovered that approximately $80 \%$ of the targeted individuals responded that they usually require less than three minutes $(300 \mathrm{~m})$ to arrive at the closest garbage collection spot. It was also revealed that more than half of the communities adhere to the rules on garbage sorting, and had installed garbage bins for separate disposal. Nonetheless, the proportion of respondents who consistently or almost frequently sort their garbage at home before discarding is less than $40 \%$. Roughly $40 \%$ of the respondents revealed that they separately discard garbage at the collection spot. Among them, $55.6 \%$ confirmed that they are intellectually equipped with the correct knowledge of garbage sorting. In contrast, about $40 \%$ of the respondents were found to sort garbage based on incorrect knowledge (see Figure 3).

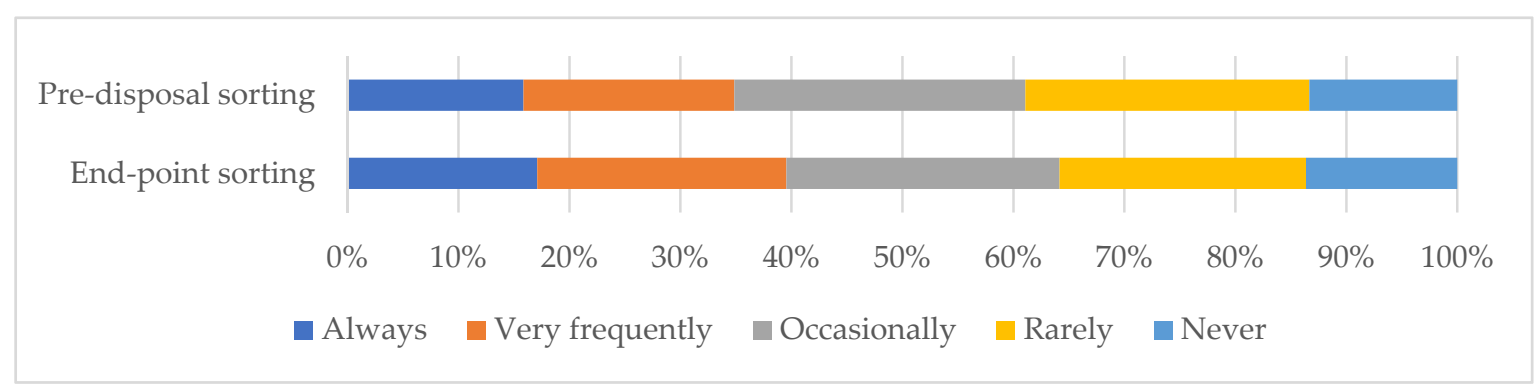

Figure 3. Behavior related to sorting household garbage. Source: authors' own calculations, 2020.

With respect to the garbage sorting program, $60 \%$ of the respondents asserted that they support it, $20 \%$ asserted that they somewhat support it, and only $1 \%$ opposed it. However, the proportion of respondents who agree or slightly agree to comply with the refuse charge system is $40 \%$ (see Figure 4). In other words, although $60 \%$ of the respondents are highly supportive of the garbage sorting program, an equal number $(60 \%)$ of them are indifferent to the refuse charge system. 
Refuse charge system

Garbage sorting program

\begin{tabular}{|c|c|c|c|c|c|c|c|c|c|c|}
\hline & $0 \%$ & $10 \%$ & $20 \%$ & $30 \%$ & $40 \%$ & $50 \%$ & $60 \%$ & $70 \%$ & $80 \%$ & $90 \%$ \\
\hline
\end{tabular}

Figure 4. Receptiveness to the refuse charge system. Source: authors' own calculations, 2020.

The survey also inquired into the environmental and moral value judgements of the respondents in relation to a 16-item scale of pro-environmental behavior and a nine-item scale of altruism (see Table 3). In creating the pro-environmental behavior scale, this study took its clues from a study by Zhao et al., and used a new approach that produces an accurate and reliable measurement based on the separate analysis of three aspects of pro-environmental behavior: purchase, use, and reuse [31].

Table 3. Pro-environmental behavior scale items.

\begin{tabular}{|c|c|c|c|c|c|c|c|c|}
\hline & SA & SWA & $\mathbf{U}$ & SWD & SD & $r_{i-t}$ & $\alpha$ & FL \\
\hline $\begin{array}{l}\text { (1) If I can avoid using disposable items, for example, } \\
\text { plastic bags and disposable dishware, } \\
\text { the environmental quality will be improved. }\end{array}$ & 37.26 & 39.36 & 14.99 & 5.37 & 3.02 & 0.336 & 0.748 & 0.423 \\
\hline $\begin{array}{l}\text { (2) If no one is protecting the environment together } \\
\text { with me, I will not do it myself. }\end{array}$ & 30.66 & 21.84 & 21.28 & 17.27 & 8.95 & 0.113 & 0.771 & 0.064 \\
\hline $\begin{array}{c}\text { (3) I always purchase home appliances with 'China } \\
\text { Environmental Labelling' or 'Energy Conservation } \\
\text { Certificate' stickers. }\end{array}$ & 56.57 & 27.51 & 12.09 & 2.65 & 1.17 & 0.517 & 0.736 & 0.634 \\
\hline $\begin{array}{l}\text { (4) I always take a taxi or use my own car when I go out. } \\
\text { I seldom take public transportations such as subways } \\
\text { and buses. }\end{array}$ & 27.21 & 23.75 & 16.1 & 18.57 & 14.37 & 0.011 & 0.783 & -0.037 \\
\hline $\begin{array}{l}\text { (5) I use my own mug cup at work instead of disposable } \\
\text { paper cups. }\end{array}$ & 72.61 & 16.59 & 5.55 & 2.47 & 2.78 & 0.459 & 0.740 & 0.587 \\
\hline $\begin{array}{l}\text { (6) I print double-sided and use both sides of paper } \\
\text { when I write too. }\end{array}$ & 55.52 & 26.77 & 11.54 & 3.89 & 2.28 & 0.550 & 0.732 & 0.664 \\
\hline $\begin{array}{l}\text { (7) I use food storage containers instead of cling wrap } \\
\text { or aluminium foil. }\end{array}$ & 43.49 & 26.96 & 17.95 & 7.9 & 3.7 & 0.462 & 0.737 & 0.568 \\
\hline $\begin{array}{l}\text { (8) I always turn off the computer when I get off or } \\
\text { when I think that it will not be used for a long time. }\end{array}$ & 64.71 & 22.52 & 7.9 & 3.02 & 1.85 & 0.561 & 0.733 & 0.664 \\
\hline (9) I always purchase and use rechargeable batteries. & 28.19 & 25.17 & 20.85 & 14.37 & 11.41 & 0.267 & 0.756 & 0.371 \\
\hline $\begin{array}{l}\text { (10) I always reuse wastewater, for example, wastewater } \\
\text { from the washing machine and washing rice. }\end{array}$ & 31.15 & 31.4 & 19.19 & 11.97 & 6.29 & 0.476 & 0.735 & 0.514 \\
\hline (11) I always purchase pens with refills or fountain pens. & 44.66 & 30.6 & 14.62 & 6.48 & 3.64 & 0.564 & 0.728 & 0.632 \\
\hline $\begin{array}{l}\text { (12) I usually throw my used clothes away directly } \\
\text { into bins. }\end{array}$ & 25.11 & 26.4 & 19.86 & 16.96 & 11.66 & 0.515 & 0.737 & 0.034 \\
\hline (13) I only use an air conditioner when it is necessary. & 61.26 & 27.27 & 7.53 & 2.41 & 1.54 & 0.086 & 0.773 & 0.594 \\
\hline (14) I will set the air conditioner at $28^{\circ} \mathrm{C}$ in the summer. & 28.19 & 28.32 & 19.74 & 13.08 & 10.67 & 0.343 & 0.748 & 0.361 \\
\hline $\begin{array}{l}\text { (15) I will set the air conditioner (heater) at } 20^{\circ} \mathrm{C} \text { in } \\
\text { the winter. }\end{array}$ & 26.1 & 30.1 & 21.28 & 11.54 & 10.98 & 0.369 & 0.745 & 0.371 \\
\hline (16) I will try to run larger and fuller loads of laundry. & 50.22 & 29.98 & 10.73 & 5.31 & 3.76 & 0.452 & 0.738 & 0.502 \\
\hline
\end{tabular}

The altruism scale was constructed as a new scale for this research. We applied the Schwartz norm-activation principles to measure altruistic attitudes (see Table 4). According to Schwartz's model, altruistic behavior arises from personal norms if two criteria are met: an individual must be aware that 
particular actions (or inactions) have consequences for the welfare of others (awareness of consequences, $\mathrm{AC}$ ), and an individual must ascribe responsibility for the consequences of those actions to himself or herself (ascription of responsibility, AR) [32,33]. The simultaneous presence of AC and AR in a specific situation enables pertinent personal norms to motivate behavior.

Table 4. Altruism scale items.

\begin{tabular}{|c|c|c|c|c|c|c|c|c|}
\hline Item & SA & SWA & $\mathbf{U}$ & SWD & SD & $r_{i-t}$ & $\alpha$ & FL \\
\hline $\begin{array}{l}\text { (1) I implement garbage sorting only when it } \\
\text { helps to lower my own expenses. }\end{array}$ & 12.95 & 19.68 & 21.84 & 28.93 & 16.59 & 0.188 & 0.403 & -0.109 \\
\hline $\begin{array}{l}\text { (2) Contributions to community organizations } \\
\text { can greatly improve the lives of others. }\end{array}$ & 1.54 & 2.28 & 11.54 & 36.21 & 48.43 & 0.293 & 0.370 & 0.755 \\
\hline $\begin{array}{l}\text { (3) The individual alone is responsible for his } \\
\text { or her satisfaction in life. }\end{array}$ & 31.71 & 29.55 & 16.66 & 13.63 & 8.45 & 0.095 & 0.447 & -0.262 \\
\hline $\begin{array}{l}\text { (4) It is my duty to help other people when } \\
\text { they are unable to help themselves. }\end{array}$ & 0.99 & 1.85 & 11.66 & 36.71 & 48.8 & 0.306 & 0.369 & 0.762 \\
\hline $\begin{array}{l}\text { (5) Many of society's problems result from } \\
\text { selfish behavior. }\end{array}$ & 1.91 & 3.64 & 16.59 & 32.63 & 45.22 & 0.134 & 0.422 & 0.580 \\
\hline $\begin{array}{l}\text { (6) Households like mine should not be } \\
\text { blamed for environmental problems caused by } \\
\text { energy production and use. }\end{array}$ & 27.82 & 26.9 & 24.98 & 14.37 & 5.92 & 0.109 & 0.437 & -0.223 \\
\hline $\begin{array}{l}\text { (7) My responsibility is to provide only for my } \\
\text { family and myself. }\end{array}$ & 22.33 & 31.65 & 18.26 & 18.88 & 8.88 & 0.253 & 0.371 & -0.097 \\
\hline $\begin{array}{l}\text { (8) Using renewable energy is the best way to } \\
\text { combat global warming. }\end{array}$ & 1.79 & 4.38 & 18.14 & 33.87 & 41.83 & 0.081 & 0.440 & 0.547 \\
\hline $\begin{array}{l}\text { (9) It is possible that my personal actions can } \\
\text { greatly improve the well-being of other } \\
\text { people. }\end{array}$ & 1.97 & 3.89 & 18.75 & 36.4 & 38.99 & 0.237 & 0.386 & 0.631 \\
\hline
\end{tabular}

Source: Authors' own calculations, 2020. Notes: SA is 'strongly agree', SWA is 'somewhat agree', U is 'unsure', SWD is 'somewhat disagree', SD is 'strongly disagree', ri-t is item-total correlations, $\alpha$ is Cronbach's coefficient alpha, and FL is factor loading. Percentages may not sum to 100 due to rounding.

Durkheim provided an eloquent analysis of the importance of moral norms in influencing human collective behavior [34]. Personal norms are perceived moral norms that represent personal beliefs about what is right and wrong when acting in a particular manner in a specific situation. Moral norms are a shared set of beliefs, values, and ideas on what is presumed to be the right behavior. They regulate social life or human affairs by guiding and restraining individual behavior and action that produces adverse consequences for other members of society. Thøgerson [35] discussed the role of social norms in restricting individualism in favor of collectivism; in 2009, Thøgerson [36] further explored the strength of a person's norms-namely, subjective social norms and personal norms-in guiding environmentally responsible behavior. Personal norms or moral norms inform our sense of identity and behavior. They represent the will of individuals to altruistically prioritize collective interest over self-interest.

The research presented here applies Schwartz's principles in the form of a general altruism scale based on Clark et al. [22]. The scale contains a total of nine items that test for the presence of individual personal norms, AC, and AR. Specific items are listed in Table 4. Items 1, 3, and 4 refer to personal norms; Items 2, 5, and 8 represent AC; and Items 6, 7, and 9 represent AR.

For the altruism scale, Cronbach's coefficient alpha was used to evaluate internal consistency. When all of the nine items were used, Cronbach's coefficient alpha was found to be 0.434 . Given this, the items with higher values (namely, Items 3,6, and 8) were eliminated from the analysis.

This study used a discrete choice model for the analysis. The objective variables considered are end-point garbage sorting behavior ('sorting behavior'), receptiveness to a refuse charge system ('receptiveness to fees'), and receptiveness to policies requiring garbage sorting ('receptiveness to policies'). The values of the garbage sorting behavior variable, an objective variable, were computed based on the responses derived from the questionnaires. These include, for example, "Do you sort 
garbage when you discard it at a collection spot in your community?" In answering the question, the respondents are required to choose one of the five response options: always, very frequently, occasionally, rarely, and never. A five-point Likert scale was used to assign values to the responses ( $5=$ always, $\ldots, 1=$ never). The variable 'receptiveness to fees' corresponds to the question, "Do you support the idea that people discarding more garbage should be charged a higher fee?" Likewise, the variable 'receptiveness to policies' is related to the question: "Do you support the garbage sorting system?" For these questions, the respondents were required to select one of the five response options: strongly agree, somewhat agree, unsure, somewhat disagree, or strongly disagree. Again, a five-point Likert scale was used to assign values to the responses as stated $(5=$ strongly agree, ... , $1=$ strongly disagree).

As shown in Table 5, the explanatory variables include: (1) EI (Knowledgeable or not knowledgeable ('Agree or not agree' in Shenyang) of the local economic incentive program: yes $=1$, no = 0), (2) PEB (the score of the pro-environmental behavior scale), (3) ALT (the score of the altruism scale), (4) OWNERSHIP (have or do not have a residential ownership: yes $=1$, no $=0$ ), (5) MANAGEMENT (the communities have or do not have a property management: yes $=1$, no $=0$ ), (6) RULE (the communities have or do not have the rules on garbage sorting: yes $=1$, no $=0$ ), (7) INFRA (the communities have or do not have the infrastructure to support garbage sorting: yes $=1$, no $=0$ ), (8) DIST (distance to the garbage collection spot: $5=$ more than or equal to $10 \mathrm{~min}$, $4=7-9 \mathrm{~min}, 3=4-6 \mathrm{~min}, 2=1-3 \mathrm{~min}, 1=$ less than $1 \mathrm{~min}$ ), (9) KNOWLEDGE (knowledge on the city's household garbage sorting regulations, derived from the answers to the question: $5=$ very familiar, 4 = familiar, 3 = have heard about, but not familiar, 2 = never heard about the regulations, but have heard about the sorting instructions, $1=$ never heard about the regulations or the sorting instructions), and (10) demographic variables including GENDER (male $=1$, female $=2$ ), AGE (above $60=5,50-59=4,40-49=3,30-39=2,18-29=1$ ), MARRIAGE (marital status, yes =1, no = 0), REGIS (household registration status, native $=1$, outsiders $=0$ ), EDUCATION (education level: postgraduate or above $=4$, undergraduate or junior college $=3$, senior high or senior secondary $=2$, junior high and below = 1), OCCUPATION (yes = 1, no = 0), INCOME (above 4001 $\$=8,3001-4000 \$=7,2501-3000 \$=6$, $2001-2500 \$=5,1501-2000 \$=4,1001-1500 \$=3,501-1000 \$=2$, less than 500\$ = 1), POLITICAL (political affiliation, member of the $\mathrm{CPC}=4$, the Communist Youth League $=3$, non-communist or minor parties $=2$, commoner or others $=1$ ), and CITY (Shanghai $=1$, Shenyang $=2$, Chengdu $=3$ ).

Table 5. Description of the explanatory variables.

\begin{tabular}{|c|c|c|c|}
\hline Explanatory Variables & Description & Mean & $\mathrm{SD}(\%)$ \\
\hline EI & $\begin{array}{l}\text { Knowledgeable or not knowledgeable ('Agree or not agree' in } \\
\text { Shenyang) of the local economic incentive program }\end{array}$ & 0.27 & 0.45 \\
\hline yes $=1$ & & & $27.45 \%$ \\
\hline no $=0$ & & & $72.55 \%$ \\
\hline$P E B$ & The score of the pro-environmental behavior scale & 62.61 & 8.49 \\
\hline$A L T$ & The score of the altruism scale & 22.57 & 3.21 \\
\hline OWNERSHIP & Have or do not have a residential ownership & 5.97 & 0.49 \\
\hline yes $=1$ & & & $59.72 \%$ \\
\hline no $=0$ & & & $40.28 \%$ \\
\hline MANAGEMENT & The communities have or do not have a property management & 0.78 & 0.41 \\
\hline yes $=1$ & & & $78.16 \%$ \\
\hline no $=0$ & & & $21.84 \%$ \\
\hline RULE & The communities have or do not have the rules on garbage sorting & 0.5 & 0.5 \\
\hline yes $=1$ & & & $50.34 \%$ \\
\hline no $=0$ & & & $49.66 \%$ \\
\hline INFRA & $\begin{array}{c}\text { The communities have or do not have the infrastructure to support } \\
\text { garbage sorting }\end{array}$ & 0.59 & 0.49 \\
\hline yes $=1$ & & & $58.54 \%$ \\
\hline no $=0$ & & & $41.46 \%$ \\
\hline
\end{tabular}


Table 5. Cont.

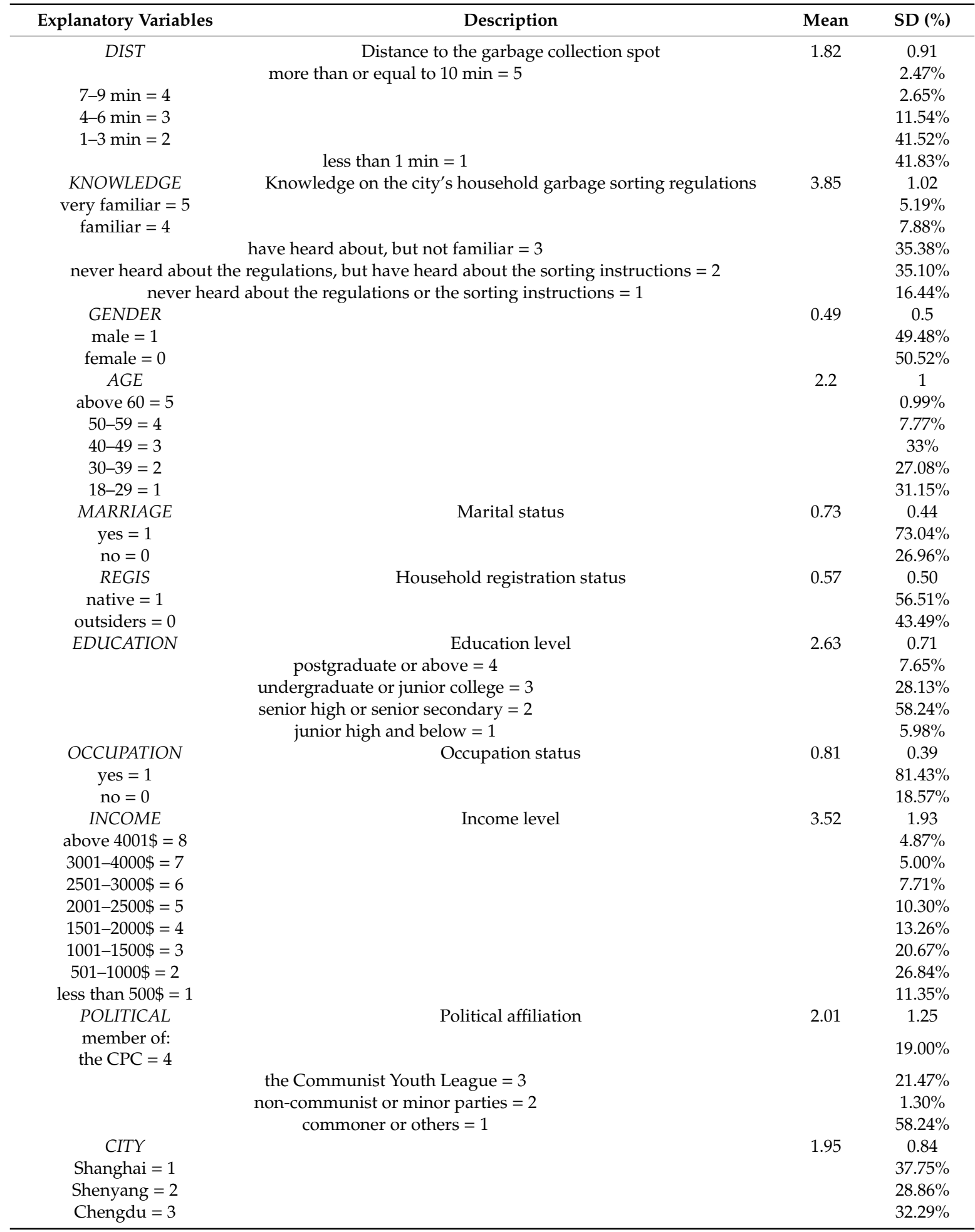

Source: authors' own calculations, 2020. Note: $\mathrm{N}=1621$, SD: Standard deviation, SD/\%: this column refers to the standard deviation (SD) unless otherwise noted (\%).

\subsection{Estimation Results}

The results of the analysis are shown in Tables 6 and 7. Table 6 shows the estimation results for all of the respondents. The estimated coefficients on PEB and EI are statistically significant in the expected direction. More specifically, the positive signs on both variables indicate that the stronger the 
environmentally friendly activities and knowledge are, the higher the probabilities of participating in the garbage sorting program, the receptiveness to fees, and the receptiveness to policies are. The result supports the idea that economic measures exert a positive impact on inducing and promoting residents' garbage sorting behavior. They also serve to increase their receptiveness to the introduction of a refuse charge program, or to policies mandating garbage sorting. Nonetheless, the altruism scale (ALT) only has a significant positive correlation with receptiveness to policies. This indicates that altruistic individuals will engage in pro-environmental behaviors when there are environmental benefits. However, when it comes to private benefits, various responses were noted. For instance, in response to the question of "What charging method do you think is appropriate if the government introduces quantity-based charging for garbage collection?", 416 respondents (the largest number) chose a designated bag system (Figure 5).

Table 6. Estimation results for all of the respondents.

\begin{tabular}{|c|c|c|c|c|c|c|}
\hline \multirow[b]{2}{*}{ Variable } & \multicolumn{3}{|c|}{ Ordinal Logit Models } & \multicolumn{3}{|c|}{ Ordinal Probit Models } \\
\hline & $\begin{array}{l}\text { Sorting } \\
\text { Behavior }\end{array}$ & $\begin{array}{l}\text { Receptiveness } \\
\text { to Fees }\end{array}$ & $\begin{array}{l}\text { Receptiveness } \\
\text { to Policies }\end{array}$ & $\begin{array}{l}\text { Sorting } \\
\text { Behavior }\end{array}$ & $\begin{array}{l}\text { Receptiveness } \\
\text { to Fees }\end{array}$ & $\begin{array}{l}\text { Receptiveness } \\
\text { to Policies }\end{array}$ \\
\hline$E I$ & $1.874^{* * *}$ & $0.706^{* * *}$ & $0.534^{* * *}$ & $1.127^{* * *}$ & $0.401 * * *$ & $0.300^{* * *}$ \\
\hline PEB & $0.033^{* * *}$ & $0.020^{* * *}$ & $0.055^{* * *}$ & $0.020 * * *$ & $0.012^{* * *}$ & $0.030^{* * *}$ \\
\hline$A L T$ & 0.013 & 0.002 & $0.141^{* * *}$ & 0.008 & 0.003 & $0.082 * * *$ \\
\hline OWNERSHIP & 0.022 & 0.106 & -0.201 & 0.029 & 0.067 & -0.11 \\
\hline MANAGEMENT & -0.1 & 0.148 & $0.365^{* *}$ & -0.069 & 0.071 & $0.215^{* * *}$ \\
\hline RULE & $1.464^{* * *}$ & 0.185 & $0.339^{* *}$ & $0.828 * * *$ & 0.105 & $0.188^{* *}$ \\
\hline INFRA & $0.709^{* * *}$ & 0.052 & -0.013 & $0.406^{* * *}$ & 0.032 & 0.006 \\
\hline DIST & 0.02 & 0.063 & $-0.098 *$ & 0.01 & 0.045 & $-0.057 *$ \\
\hline GENDER & $0.154 *$ & $0.313^{* * *}$ & 0.117 & 0.075 & $0.186^{* * *}$ & 0.058 \\
\hline$A G E$ & 0.108 ** & $0.144^{* * *}$ & 0.056 & 0.061 * & $0.086^{* * *}$ & 0.035 \\
\hline MARRIAGE & -0.159 & 0.079 & 0.08 & -0.088 & 0.067 & 0.055 \\
\hline REGIS & $-0.254^{* *}$ & -0.166 & $-0.360^{* * *}$ & $-0.159 * *$ & $-0.111 *$ & $-0.218^{* * *}$ \\
\hline EDUCATION & $-0.221 * * *$ & -0.007 & -0.038 & $-0.133^{* * *}$ & -0.013 & 0.002 \\
\hline OCCUPATION & $0.261^{* *}$ & 0.146 & 0.206 & $0.145^{* *}$ & 0.091 & 0.115 \\
\hline INCOME & 0.026 & $0.045^{*}$ & 0.021 & 0.015 & 0.030 * & 0.011 \\
\hline POLITICAL & 0.059 & 0.05 & $0.082 *$ & $0.039 *$ & 0.033 & $0.047^{*}$ \\
\hline CITY & 0.029 & $0.139^{* *}$ & $0.253^{* * *}$ & 0.01 & $0.081^{* *}$ & $0.130^{* * *}$ \\
\hline chi2 & 911.259 & 145.688 & 303.707 & 910.965 & 143.944 & 299.89 \\
\hline$R$-squared & 0.177 & 0.028 & 0.098 & 0.177 & 0.028 & 0.097 \\
\hline$N$ & 1621 & 1621 & 1621 & 1621 & 1621 & 1621 \\
\hline
\end{tabular}

Source: authors' own calculations, 2020. Note: the symbols ${ }^{*}, * *$, and ${ }^{* * *}$ indicate significance at the $10 \%, 5 \%$, and $1 \%$ levels, respectively.

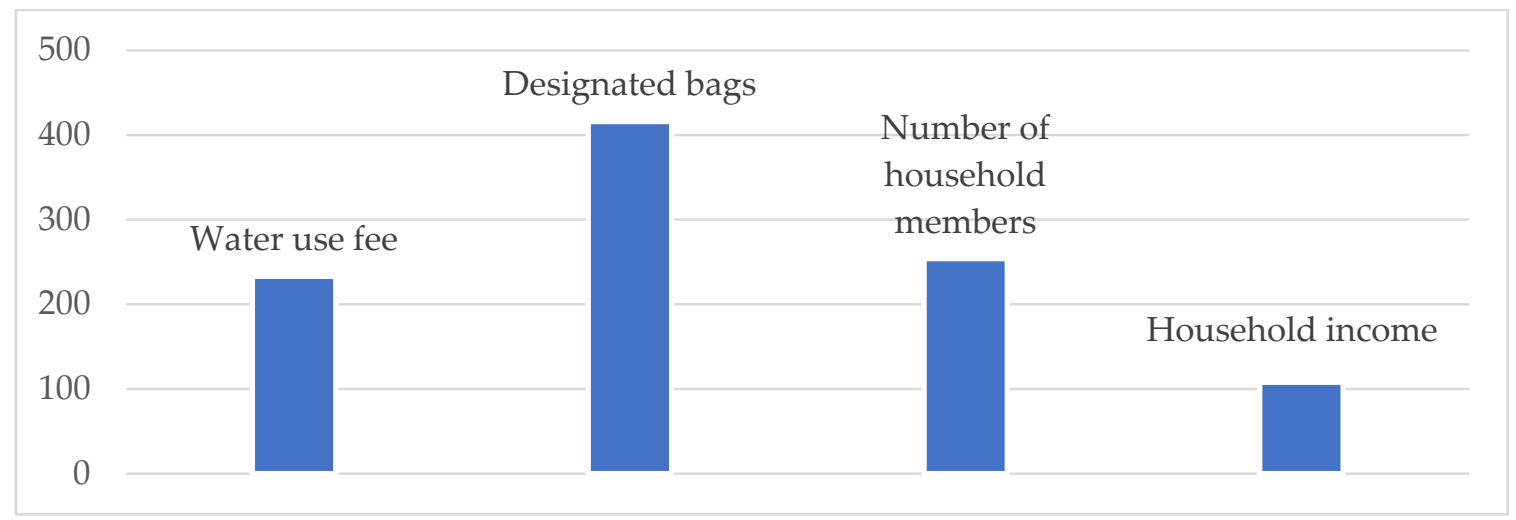

Figure 5. The refuse charge system. Source: authors' own calculations, 2020.

However, in response to the further question of "How much are you willing to pay if a designated bag system is introduced?", approximately $60 \%$ of the respondents indicated 0.01 to 0.02 yuan, which is, by any standard, surprisingly low (Figure 6). Implicitly, even though some respondents revealed that they support a refuse charge system, they are egoistically unwilling to bear any financial burden. 
This contradicts Schwartz's principles of altruism, in that the awareness of consequences (AC) did not lead to the ascription of responsibility. In other words, these respondents displayed a high self-interest, and are unwilling to engage in pro-environmental behavior or action in the presence of a perceived cost of sacrifice, as expressed in terms of a financial burden.

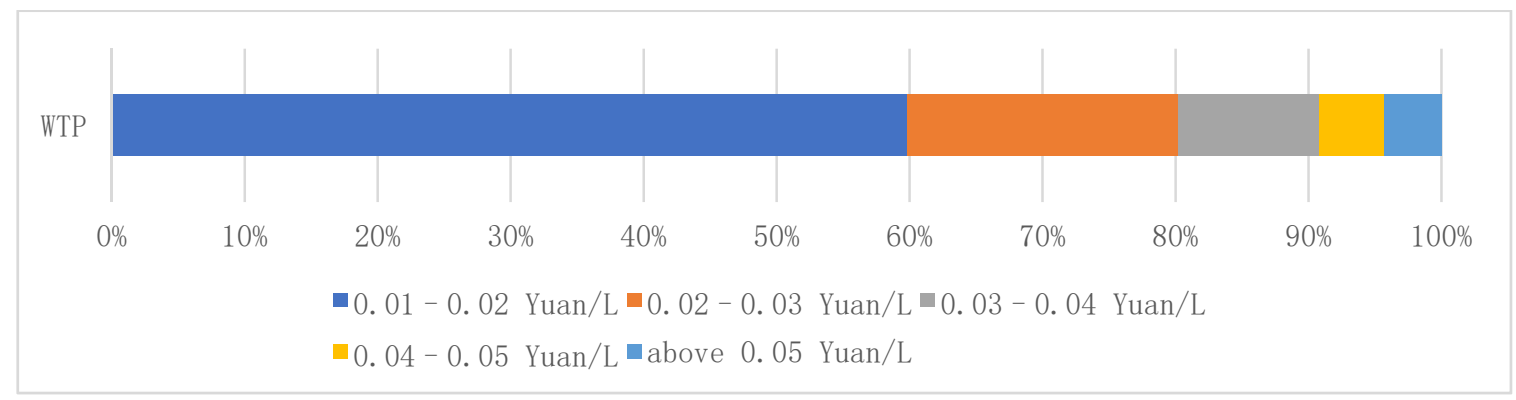

Figure 6. WTP (Willingness to Pay) for waste collection. Source: authors' own calculations, 2020.

The signs and coefficients for $A G E$ indicate that the elderly are more likely to participate in the garbage sorting program, and display a higher receptiveness to fees. One reason for these tendencies could be that the young workers are unable to freely join sorting efforts that are scheduled during specific hours in the morning and evening in areas where the separate collection and disposal of HSW is implemented. There is also an asymmetric information issue. It may well be that campaigns to advertise the Green Account, the Green Earth program, the refuse charge system, and policies related to garbage sorting are mostly held during the daytime, with the consequence that the information fails to reach young workers. This may be one of the main factors that impede the wider recognition and adoption of sustainable HSW programs and policies or refuse charge systems among the younger population.

GENDER positively correlates with receptiveness to fees. That is, males were shown to be more likely to support a refuse charge system. The signs and significance of OCCUPATION indicate that people who have a stable job are more likely to become 'willing' participants. This may be attributed to the fact that businesses are more effective and quicker at educating employees on policies requiring garbage sorting and actual waste sorting. However, OCCUPATION does not have an effect on the receptiveness to fees and the receptiveness to policies. The signs and significance of INCOME show that the higher an income is, the higher the willingness to pay the refuse charge is.

Furthermore, the coefficients for MARRIAGE and OWNERSHIP are not significantly deviated from zero, indicating that neither affects the probability of participation, receptiveness to fees, or receptiveness to policies. The estimated coefficients on EDUCATION were found to be statistically significant in the negative direction of the garbage sorting behavior; that is, the higher a person's education level is, the less likely he or she will be willing to engage in garbage sorting. This result contradicts existing studies.

One the main reasons behind the above contradicting trend is that people with higher education levels tend to work longer. Hence, if sorted garbage is scheduled to be collected during specific hours in the morning and evening, as mentioned above, these people, in most cases, are not able to participate in HSW separation and collection. The signs and significance of REGIS indicate that the 'outsiders', who do not have a household registration for their area of residence, are more likely to be willing participants. They also displayed a higher receptiveness to policies. This result is in contrast to what was expected before the estimation. One of the main contributing factors behind this deviation is probably due to the 'sense of place' psychological factor of the 'outsiders', which leads to an increase of their feeling of identification, and to a positive change in their strength of relationship with the environment within which they exist. Choy $[23,24]$ empirically established a strong relationship between the indigenous peoples' close attachment to the natural environment (sense of place) and their strong altruistic inclination for environmental protection, based on field research conducted in the tropical forest in Borneo, Malaysia. Choy [25] examined the values that the forest-dwelling indigenous 
people placed on the forested environment that they called home. He classified this as a 'sense of place' value. Semken [37] provides a good discussion of the strong sense of place of the American Indian and Alaskan Native people.

POLITICAL has a significantly positive correlation with behavior and receptiveness to policies, although its magnitude is small. It seems that members of the CPC display not only a stronger environmental awareness, but also a higher receptiveness to policies than the general public at large. One reason behind this pro-environmental inclination could be that, in the garbage separation pilot area, Primary Party organizations also play a key role in garbage sorting, and members of the CPC have acquired a green habit of actively taking part in garbage sorting [38,39]. This spontaneously sets an example to inspire and induce their neighbors and relatives to adopt environmentally friendly practices by introspection. This result also supports existing studies, such as Ghorbani et al. [21].

For matters governing the disposal of the sorted household garbage, the estimated coefficients on RULE imply that communities which establish garbage sorting rules are more likely to participate in a garbage sorting program. They also revealed a higher receptiveness to waste management policies. However, as regards INFRA, the existence of proper equipment at the garbage collection spot significantly and positively impacts garbage sorting behavior. The signs and coefficients for MANAGEMENT indicate that communities with a property management company show a higher level of receptiveness to policies. More specifically, in a community with a property management company, the company undertakes the task of sorting the garbage on behalf of the residents. This reduces the burdens of the residents. Inexorably, this tends to induce a moral sense of obligation incumbent upon the residents to react positively to policies requiring garbage sorting. The coefficients for DIST show that the more time required to arrive at the collection spot, the less receptive the individuals are to policies requiring garbage sorting.

Additionally, the estimated coefficients on CITY statistically, significantly, and positively correlate with the receptiveness to fees and to policies. This implies that there are differences in receptiveness to fee and policy support among cities.

The estimation results for the respondents who perform end-point sorting are shown in Table 7. The results of the estimation are similar to those of the case with all of the respondents. However, the coefficients for MANAGEMENT, DIST, MARRIAGE, and POLITICAL are not significantly correlated with the objective variables, indicating that none of them affect the probability of participation, receptiveness to fees, or receptiveness to policies.

The signs and significance of INCOME show that people with a higher income are more likely to take part in garbage sorting. OCCUPATION is also significantly and positively correlated with the receptiveness to policies. It seems that because businesses are quick to educate employees on policies requiring garbage sorting and actual sorting wastes, they have contributed to the enhancement of individuals' receptiveness to such policies. The estimated coefficients on AGE are not statistically significant with respect to sorting behavior and the receptiveness to policies. On the other hand, RULE and INFRA have a significantly positive correlation with garbage sorting behavior. The estimated coefficients on KNOWLEDGE were found to be statistically, significantly, and positively correlated with garbage sorting behavior, the receptiveness to fees, and the receptiveness to policies. It seems that the knowledge of the city's household garbage sorting regulations stimulates people to participate in the garbage sorting program. This has the effect of boosting their receptiveness to fees.

The estimation results show that garbage sorting behavior, the receptiveness to fees, and the receptiveness to policies significantly vary across the three cities. An analysis with propensity score matching was also performed. The receptiveness to fees and the receptiveness to policies were set as outcomes, the existence of economic incentives was set as an assignment variable, and the respondents' attributes were set as covariates. All of the coefficients were negative. In other words, compared with the residents in Shanghai and Chengdu, where economic incentive measures such as the Green Account and the Green Earth program have been introduced, the residents of Shenyang, where such 
measures are non-existent, were found to engage more actively in garbage sorting. They are also more receptive to a refuse charge system and policies requiring garbage sorting.

Table 7. Estimation results for respondents who perform end-point sorting.

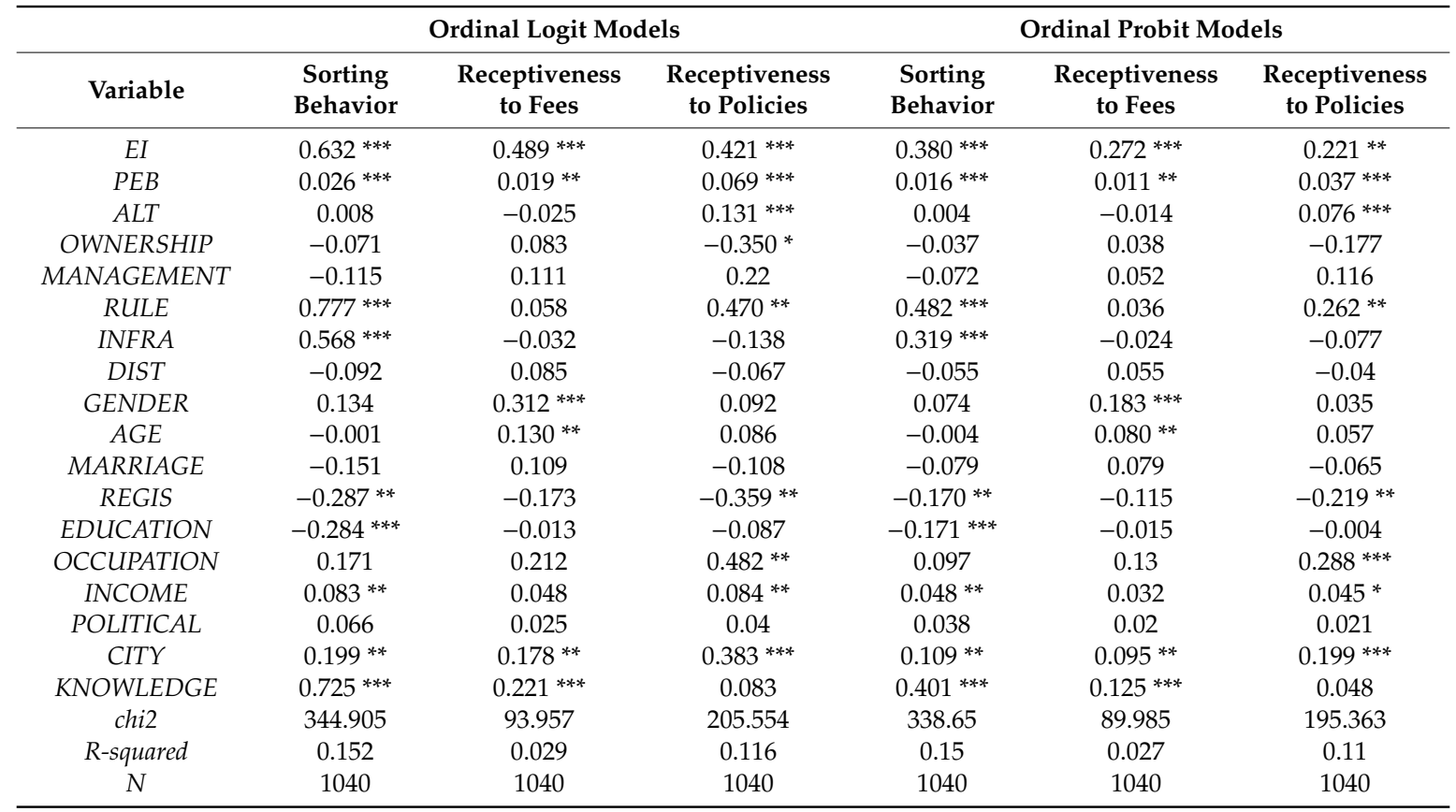

Source: authors' own calculations, 2020 . Note: the symbols $*{ }^{* *}$, and ${ }^{* * *}$ indicate significance at the $10 \%, 5 \%$, and $1 \%$ levels, respectively.

\subsection{Overall Estimate Outcomes and Policy Implications}

All of the study areas clearly show that many factors influence residents' sustainable waste disposal behavior and practice. These may be widely divided into the following categories:

(i). Personal characteristics, such as gender, marital status, education, age, and a sense of belonging or sense of place, among others.

(ii). Economic characteristics, such as a reward system or government incentives (for example, movie tickets or park tickets, as mentioned above).

(iii). Attitudinal variables, such as environmental beliefs in relation to the change in attitude towards waste problems.

(iv). In relation to (iii), attitudinal variables are highly dependent on the promotion of environmental and moral education, such as the promotion of the concepts of the Ecological Civilization (ecocentric environmental beliefs and the ethic of altruism).

(v). Other related variables, such as political influence in relation to the spread of environmentally friendly practices, or the time required for HSW management and to arrive at a garbage collection spot or recycling center (here, it may be remarked that all of the study areas showed that the shorter the distance to the garbage collection spot is, the larger the impact factor is on environmental behavioral change).

Furthermore, the analysis based on the external variables indicates that the participants of the garbage sorting program tend to live in communities that have clear rules on garbage sorting and have installed the proper equipment at garbage collection spots. Additionally, the development of the solid waste management infrastructure-such as smart garbage collecting stations that are designed to recognize different types of waste automatically — can encourage citizens to cooperate with the local government in waste sorting. 
The analysis also uncovered the interesting fact that participants of the garbage sorting program tend to be elderly and employed. In addition, the study revealed a lesser known, let alone well-analyzed, issue that the 'sense of place' can serve as a crucially important intrinsic impact factor in inducing an individual's green behavioral practices.

Our investigation also uncovered the important fact that the power of the external influence arising from politically influential and environmentally inclined elites, such as CPC members, is positively related to the state of green environmental consciousness or the green mentality of the individuals surrounding them. These findings reflect the combined significance of external and internal moderations, and the importance of advertising and educational activities with respect to the garbage sorting policies in each community. In the future, the local government could optimize the use of metro or subway advertising media or social media such as WeChat or Tiktok in order to disseminate information concerning sustainable waste disposal practices. These critical measures also serve to induce communities to strengthen their waste sorting rules and set up their waste collection spots properly.

Our study further revealed that residents' receptiveness to a refuse charge system varies across cities, and many respondents tend to oppose the implementation of a refuse charge program. It was also found that, if a fee-based system were introduced, a designated bag system would be the most effective to draw support from the residents. In addition, compared with the residents in Shanghai and Chengdu, residents from Shenyang-where economic incentive measures have not been introduced are found to be more actively engage in garbage sorting. They are also more receptive to a refuse charge system and policies requiring garbage sorting. This implies that mandatory garbage sorting would be more effective than economic measures.

\section{Conclusions}

The present study examined residents' garbage sorting behavior based on a questionnaire survey, and clarified the factors that contribute to their green cooperation and other environmental morality issues in three selected regions, namely, Shanghai, Shenyang (Liaoning Province), and Chengdu (Sichuan Province). The accumulated data, which was analyzed using ordinal logit models and ordinal probit models, indicated that pro-environmental behavior arising from environmental awareness is a significant explanatory variable in promoting personal norms in HSW sorting habits and the social endorsement of refuse charge systems and policies, in line with the concept of an ecological civilization. Altruism appears to influence the receptiveness to policies only. However, both altruism and environmental awareness are preconditions for the enhancement of pro-environmental behavior and regulative environmental observance.

Overall, our findings ineluctably signal the sovereign importance of environmental and moral education in inducing and promoting personal norms in sustainable HSW management and practices. This is all the more necessary because it is infeasible for a government to strictly monitor daily household residents' HSW sorting behavioral practices due to the massive monitoring cost involved. That said, it is through further publicity, and environmental and moral education, that household residents can determine what must be valued in green development, and what actions must be taken to be in line with the Ecological Civilization philosophy that is rigorously promoted by the government.

Our study has far-reaching implications that the repertory of regulative control or legislative constraint alone is far from adequate to effectively hold society accountable for sustainable HSW management practices. What is important is to inculcate a collective moral interest through various educational activities and a moral sense that can bind a society towards embracing an Ecological Civilization, as discussed above. Working incisively in tandem with regulative control, environmental and moral education can serve as an effective means of promoting an 'ecologically civilized' society par excellence. 
Author Contributions: Conceptualization, Y.H. and H.K.; methodology—formal analysis, Y.H.; writing—original draft preparation, Y.H.; supervision, H.K.; funding acquisition, H.K.; writing-review and editing, Y.C.; data curation, X.K.; validation, P.T. All authors have read and agreed to the published version of the manuscript.

Funding: This work was supported by JSPS KAKENHI Grant Number 16K12664. Any opinions, findings, and conclusions or recommendations expressed in this material are those of the author(s) and do not necessarily reflect the views of the author(s)' organization, JSPS, or MEXT.

Conflicts of Interest: The authors declare that there is no conflict of interest.

\section{References}

1. Kaza, S.; Yao, L.C.; Bhada-Tata, P.; Van Woerden, F. What a Waste 2.0: A Global Snapshot of Solid Waste Management to 2050. In Urban Development; World Bank: Washington, DC, USA, 2018. Available online: https://openknowledge.worldbank.org/handle/10986/30317 (accessed on 10 October 2020).

2. Chen, D.M.-C.; Bodirsky, B.L.; Krueger, T.; Mishra, A.; Popp, A. The world's growing municipal solid waste: Trends and impacts. Environ. Res. Lett. 2020, 15, 074021. [CrossRef]

3. World Bank. Solid Waste Management. 2019. Available online: https:/www.worldbank.org/en/topic/ urbandevelopment/brief/solid-waste-management (accessed on 10 October 2020).

4. Ferrara, I. Waste Generation and Recycling. In Household Behaviour and the Environment. Reviewing the Evidence; OECD: Paris, France, 2008; pp. 19-58. Available online: https://www.oecd.org/environment/consumptioninnovation/42183878.pdf (accessed on 10 October 2020).

5. The Ministry of Housing and Urban-Rural Development. China Urban-Rural Construction Statistical Yearbook 2017; China Statics Press: Beijing, China, 2018. Available online: http://www.stats.gov.cn/tjsj/ (accessed on 20 March 2020). (In Chinese)

6. Yang, Q.; Zhu, Y.; Liu, X.; Fu, L.; Guo, Q. Bayesian-Based NIMBY Crisis Transformation Path Discovery for Municipal Solid Waste Incineration in China. Sustainability 2019, 11, 2364. [CrossRef]

7. Huang, X.; Yang, D.L. NIMBYism, waste incineration, and environmental governance in China. China Inf. 2020, 34, 342-360. [CrossRef]

8. Goron, C. Ecological Civilisation and the Political Limits of a Chinese Concept of Sustainability. China Perspect. 2018, 39-52. [CrossRef]

9. Wang, H.; Jiang, C. Local Nuances of Authoritarian Environmentalism: A Legislative Study on Household Solid Waste Sorting in China. Sustainability 2020, 12, 2522. [CrossRef]

10. The State Council. Notice on the Opinions on Further Strengthening the Work of Municipal Solid Waste Disposal. 2011. Available online: http://www.gov.cn/zwgk/2011-04/25/content_1851821.htm (accessed on 20 March 2020). (In Chinese)

11. The State Council General Office. The Proposed Method of Implementing the Sorting System for Municipal Solid Waste. 2017. Available online: http://www.gov.cn/zhengce/content/2017-03/30/content_5182124.htm (accessed on 20 March 2020). (In Chinese)

12. Yokoo, H.; Wada, H.; Yamada, M. 家庭ごみ分別制度と社会的規範: 一日本とシンガポールにおけるアンケー 卜調査の比較一. Review of Environmental Economics and Policy Studies. Soc. Environ. Econ. Policy Stud. 2014, 8, 85-88. [CrossRef]

13. Linde'N, A.-L.; Carlsson-Kanyama, A. Environmentally Friendly Disposal Behaviour and Local Support Systems: Lessons from a metropolitan area. Local Environ. 2003, 8, 291-301. [CrossRef]

14. Antonides, G.; Fred, W. Consumer Behaviour. A European Perspective; Wiley: Hoboken, NJ, USA, 1999; pp. 514-515.

15. Lindhqvist, T. Extended Producer Responsibility in Cleaner Production: Policy Principle to Promote Environmental Improvements of Product Systems; IIIEE; Lund University: Lund, Sweden, 2000. Available online: https: //lup.lub.lu.se/search/ws/files/4433708/1002025.pdf (accessed on 20 March 2020). 
16. Dahlén, L.; Lagerkvist, A. Evaluation of recycling programmes in household waste collection systems. Waste Manag. Res. 2009, 28, 577-586. [CrossRef]

17. Chappells, H.; Klintman, M.; Lindèn, A.L.; Shove, E.; Spaargaren, G.; van Vliet, B. Domestic Consumption, Utility Services and the Environment; Final Domus Report; Wageningen University: Wageningen, The Netherlands, 2000.

18. Judge, R.; Becker, A. Motivating Recycling: A Marginal Cost Analysis. Contemp. Econ. Policy 1993, 11, $58-68$. [CrossRef]

19. Ando, A.W.; Gosselin, A.Y. Recycling in multifamily dwellings: Does convenience matter? Econ. Inq. 2005, 43, 426-438. [CrossRef]

20. Van Houtven, G.L.; Morris, G.E. Household Behavior under Alternative Pay-as-You-Throw Systems for Solid Waste Disposal. Land Econ. 1999, 75, 515-537. [CrossRef]

21. Ghorbani, M.; Gunderson, M.; Lee, Y.S.B. Union and Communist Party Influences on the Environment in China. Ind. Relat. 2019, 74, 552-576. [CrossRef]

22. Clark, C.F.; Matthew, J.K.; Michael, R.M. Internal and external influences on pro-environmental behavior: Participation in a green electricity program. J. Environ. Psychol. 2003, 23, 237-246. [CrossRef]

23. Choy, Y.K. Land Ethic from the Borneo Tropical Rainforests in Sarawak, Malaysia: An Empirical and Conceptual Analysis. Environ. Ethics 2014, 36, 421-441. [CrossRef]

24. Choy, Y.K. Cost-benefit Analysis, Values, Wellbeing and Ethics: An Indigenous Worldview Analysis. Ecol. Econ. 2018, 145, 1-9. [CrossRef]

25. Choy, Y.K. Global Environmental Sustainability: Case Studies and Analysis of the United Nations' Journey toward Sustainable Development; Elsevier: Amsterdam, The Netherlands; Oxford, UK; Cambridge, CA, USA, 2020.

26. Rylander, D.; Allen, C. Understanding Green Consumption Behavior: Toward an Integrative Framework. Am. Mark. Assoc. Winter Educators' Conf. Proc. 2001, 12, 386-387.

27. National Bureau of Statistics of China. Available online: http://data.stats.gov.cn/ (accessed on 20 March 2020). (In Chinese)

28. The Information Is Based On Interviews (Conducted On 16-17 August 2017) with a Representative from Shanghai Laogang Solid Waste Utilization Co., Ltd., Ms. Qi Yumei (Deputy Chief) and Mr. Yuehua Zhang of the Environmental Sanitation Management Office of the Shanghai Landscaping and City Appearance Administrative Bureau, and Ms. Liqiong Hao (Director) of the Shanghai IFINE Environmental Protection Organization, and Information from Green Account Website. Available online: https://www.greenfortune.sh. cn/dist/index.html (accessed on 20 March 2020). (In Chinese).

29. Zhou, M.H.; Shen, S.L.; Xu, Y.S.; Zhou, A.N. New Policy and Implementation of Municipal Solid Waste Classification in Shanghai, China. Int. J. Environ. Res. Public Health 2019, 16, 3099. [CrossRef] [PubMed]

30. Chengdu Green Earth Environment Technology Co. Available online: http://www.lvsediqiu.com (accessed on 16 August 2020). (In Chinese).

31. Zhao, H.H.; Gao, Q.; Wu, Y.P.; Wang, Y.; Zhu, X.D. What affects green consumer behavior in China? A case study from Qingdao. J. Clean. Prod. 2014, 63, 143-151. [CrossRef]

32. Schwartz, S.H. Elicitation of Moral Obligation and Self-Sacrificing Behavior: An Experimental Study of Volunteering to Be a Bone Marrow Donor. J. Personal. Soc. Psychol. 1970, 15, 283-293. [CrossRef]

33. Schwartz, S.H. Normative Influences on Altruism. Adv. Exp. Soc. Psychol. 1977, 10, 221-279.

34. Durkheim, E. Emile Durkheim on Morality and Society. Selected Writings; Robert, N.B., Ed.; The University of Chicago Press: Chicago, IL, USA; London, UK, 1973.

35. Thøgerson, J.; Biel, A. Activation of social norms in social dilemmas: A review of the evidence and reflections on the implications for environmental behaviour. J. Econ. Psychol. 2007, 28, 93-112. [CrossRef]

36. Thøgersen, J. The Motivational roots of norms for environmentally responsible behaviour. Basic Appl. Soc. Psychol. 2009, 31, 348-362. [CrossRef]

37. Semken, S. Sense of place and place-based introductory geoscience teaching for American Indian and Alaska native undergraduates. J. Geosci. Educ. 2018, 53, 149-157. [CrossRef] 
38. Beijin Review. A Use for Refuse -Garbage Sorting Becomes Mandatory for a Cleaner Environment and a More Civilized Society. 2019. Available online: http://www.bjreview.com/Current_Issue/Editor_Choice/ 201908/t20190819_800176310.html (accessed on 11 October 2020).

39. Shanghai Municipal People's Government. Press Release for 28 June 2019. Available online: http: //sh.eastday.com/m/20190628/u1ai12629076.html (accessed on 11 October 2020). (In Chinese).

Publisher's Note: MDPI stays neutral with regard to jurisdictional claims in published maps and institutional affiliations.

(C) 2020 by the authors. Licensee MDPI, Basel, Switzerland. This article is an open access article distributed under the terms and conditions of the Creative Commons Attribution (CC BY) license (http://creativecommons.org/licenses/by/4.0/). 